\title{
REFRACTORY PEMPHIGUS VULGARIS ASSOCIATED WITH HERPES INFECTION: CASE REPORT AND REVIEW
}

Maria Luiza Figueiredo Braga BRANDÃO(1), Nurimar C. FERNANDES(1), Danielle Pereira de Oliveira BATISTA(2) \& Norma SANTOS(2)

\begin{abstract}
SUMMARY
Background: Pemphigus vulgaris (PV) is an autoimmune disease characterized by blistering of the skin and mucosa, which develops due to the interaction between predisposing genetic and environmental factors. Infections caused by members of the Herpesviridae family have been suggested as a possible triggering factor for PV. Objective and Methods: In this report, we investigate the presence of herpesviruses in refractory lesions on the right upper eyelid. The lesion has persisted despite the treatment with corticosteroids. Polymerase chain reaction (PCR) and DNA sequence analysis have been used to detect the DNA of HSV 1/2, VZV, EBV, CMV, HHV-6, HHV-7, and HHV-8. Results: The sample collected from the right upper eyelid has tested positive for HSV 1/2. Sequence analysis has confirmed the PCR results and allowed the identification of the HSV strain as belonging to type 1. After treatment with acyclovir, the lesion of the right upper eyelid has cleared and not relapsed. Conclusion: When patients present PV lesions which are refractory to corticosteroid therapy, herpetic infection should be considered.
\end{abstract}

KEYWORDS: Phemphigus; Herpes virus infection; Autoimmunity.

\section{INTRODUCTION}

Pemphigus vulgaris (PV) is an intraepidermal disease, characterized by blistering of the skin and mucosa ${ }^{6,8}$, which can lead to death. It occurs equally in both genders, mainly between the fourth and sixth decades of life ${ }^{6}$. It is a world-wide disease, but it is more common among Jews ${ }^{6}$.

Patients with PV present pathogenous antibodies (IgG1 and IgG4)22 against desmoglein 1 and desmoglein 3 (mucocutaneous involvement) or only against desmoglein 3 (exclusive mucosal involvement) $1,2,8,26$. Desmoglein 1 and 3 are transmembrane proteins of 160 and $130 \mathrm{Kd}$ respectively, which compose the desmosome with the function of cell adhesion of the epidermis ${ }^{6,19}$. The blister in PV is typically suprabasal and it results from the loss of cohesion of the keratinocytes, as a consequence of the interference with the function of adhesion of the desmosomal protein, via anti-desmoglein ${ }^{6}$ circulating antibodies.

The exact etiology and pathogenesis of PV are still not fully known, but it is considered that the disease results from an interaction between endogenous (genetic predisposition) and exogenous factors ${ }^{3,4}$.

Ultraviolet radiation, X-rays, drugs (principally those containing thiol and/or phenol groups), neoplasms, pregnancy, emotional stress, vaccinations, nutritional issues, and viruses are exogenous factors linked to the etiopathogenesis of $\mathrm{PV}^{3,4,20,21}$. It is known that infectious agents, such as herpes simplex virus (HSV), Epstein-Barr virus (EBV), cytomegalovirus (CMV), and herpes virus 8 (HHV 8), play an important role to initiate and trigger the disease and also to maintain and exacerbate $\mathrm{it}^{21}$.

The first study suggesting the role of viruses, principally herpes simplex, in the pathogenesis of pemphigus ${ }^{4,14,15,25}$ was published in 1974 . Since then case reports and research studies supporting this association have been published (Table 1).

The classic treatment for patients with PV is the corticosteroid therapy in immunosuppressive doses until inducing the remission of the picture, followed by minimal doses able to maintain the remission. In many cases, it is necessary to use adjuvant drugs, such as cyclophosphamide and azathioprine, in order to avoid steroids and increase their effectiveness. The introduction of corticosteroids has dramatically changed the prognosis of patients ${ }^{8}$ with $\mathrm{PV}$, modifying the mortality rate from $90 \%$ to approximately $5 \%^{6}$.

In this study, we have used the PCR method to identify DNA sequences of the principal viruses found in literature as factors associated with the refractoriness of PV lesions to conventional treatment. Our objectives have been to emphasize the importance of laboratorial tests in PV patients with recalcitrant lesions and to present a critical view of the interpretation of their results. 
BRANDÃO, M.L.F.B.; FERNANDES, N.C.; BATISTA, D.P.O \& SANTOS, N. - Refractory pemphigus vulgaris associated with herpes infection: case report and review. Rev. Inst. Med. Trop. Sao Paulo, 53(2): 113-7, 2011

Table 1

Series association of pemphigus $\mathrm{x}$ viral infection (HSV and CMV)

\begin{tabular}{|c|c|c|c|c|}
\hline Name & Number of cases & Virus & Method of diagnosis & Reference/Year \\
\hline RUOCCO et al. & 1 & CMV & serology & $10(1982)$ \\
\hline GRUNWALD et al. & 1 & HSV & sampling + serology & $20(1986)$ \\
\hline BROWN et al. & 1 & HSV & sampling + serology & $21(1989)$ \\
\hline PRENDIVILLE et al. & 1 & HSV & sampling & $22(1994)$ \\
\hline SCHLUPEN et al. & 3 & HSV & PCR & $23(1996)$ \\
\hline TUFANO et al. & 10 & HSV & $\mathrm{PBMC}+\mathrm{bx}$ & 24 (1999) \\
\hline KALRA et al. & 11 & HSV/CMV & sampling + serology + immunohistochemical & $25(2005)$ \\
\hline OLIVEIRA et al. & 1 & HSV & PCR & $26(2009)$ \\
\hline
\end{tabular}

$\mathrm{HSV}=$ Herpes simplex CMV = cytomegalovirus; $\mathrm{PCR}=$ polymerase chain reaction; $\mathrm{PBMC}=\mathrm{PCR}$ in mononuclear cells of peripheral blood; immuno $=$ immunohistochemical; bx = biopsy

\section{CASE REPORT}

M.L.A.M., 50 years old, hypertensive, diabetic, with reduced visual acuity due to bilateral posterior subcapsular cataracts related to corticosteroid therapy, PV patient with clinical and histopathological diagnosis in 2005, maintaining stable disease with the use of prednisone (20 mg/day) and cyclophosphamide pulses every 21 days.

During the follow-up, she had an episode of herpes simplex, diagnosed clinically by grouped vesicles on an erythematous base in eyelid area, top and bottom right, and was treated with oral acyclovir.

About a month after the event, the patient developed acute exacerbation of PV. Her dermatological examination revealed an exulceration about $10 \mathrm{~cm}$ above and below the right periorbital region, an exulceration in the parietal region of the scalp, a number of exulcerated lesions with meliceric crusts and several sizes in the left scapular region, an exulceration in the hard palate on the right, and a blister of hemorrhagic content in the jugal mucosa on the left.

The patient was hospitalized. The dose of prednisone was increased to $1 \mathrm{mg} / \mathrm{kg} /$ day ( $60 \mathrm{mg} /$ day) and dexamethasone pulses every 21 days were added. Cyclophosphamide pulses every 21 days were maintained.

After 40 days of hospitalization, the patient presented good reepithelialization of the lesions, but maintained an uxulcerated area of about $2 \mathrm{~cm}$ in the right upper eyelid with no signs of healing (Fig. 1). Four samples were collected with a sterile swab in the right upper eyelid lesion to search for viral DNA by the PCR method (Table 2).

We started treatment for the herpetic infection with acyclovir $400 \mathrm{mg}$, five times per day, during five days. Afterwards, this was changed to 800 mg twice a day. As there were no clinical signs of active CMV infection, we decided not to carry out a particular treatment with gancyclovir. Twenty-five days after the introduction of the antiviral, the periorbital lesion presented a 50\% reduction, approximately. Forty days after the beginning of treatment, there was a complete re-epithelialization of the lesion (Fig. 2). With the success of treatment, the patient underwent two cataract surgeries, one of them during the hospitalization previously cited.

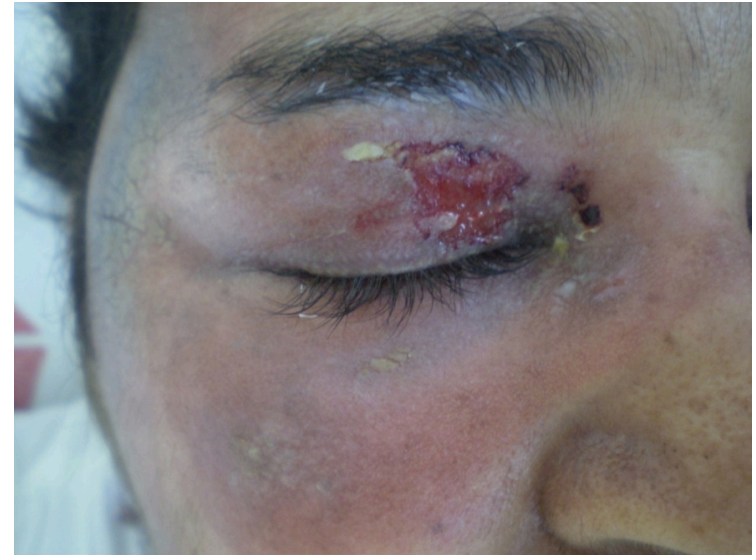

Fig. 1 - Exulcerated area in the right upper eyelid.

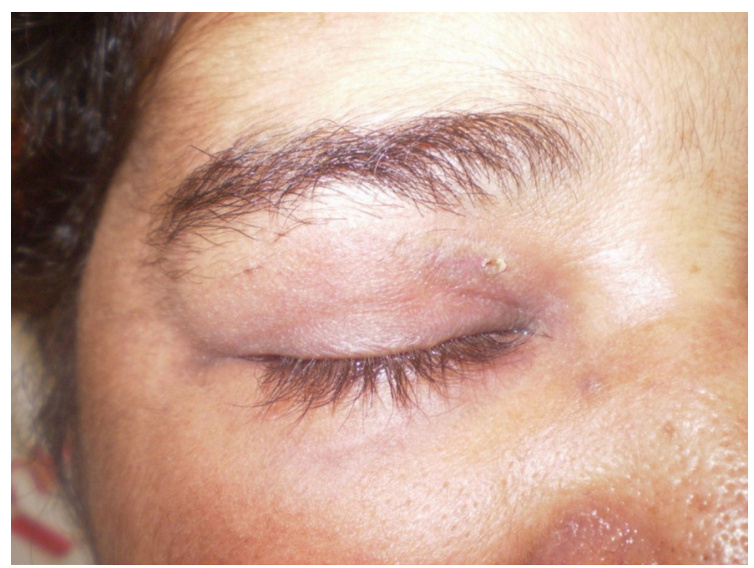

Fig. 2 - Complete re-epitheliazation.

\section{MATERIAL AND METHODS}

Study approval was given by the local ethics committee of Hospital Universitário Clementino Fraga Filho/Federal University of Rio de Janeiro, Rio de Janeiro, Brazil. 


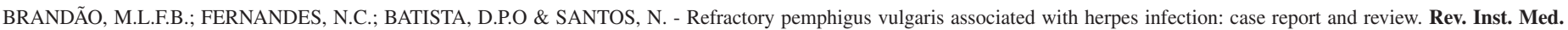
Trop. Sao Paulo, 53(2): 113-7, 2011.

Table 2

Results for viral DNA by PCR method in PV lesions (patient M.L.A.M.)

\begin{tabular}{llc}
\hline Data of swab sample & \multicolumn{1}{c}{ Area } & Results \\
\hline $25 / 06 / 09$ & right upper eyelid & CMV \\
$06 / 08 / 09$ & right upper eyelid & negative \\
$13 / 08 / 09$ & right upper eyelid & HSV \\
$16 / 09 / 09$ & right upper eyelid & negative \\
\hline
\end{tabular}

$\mathrm{PCR}=$ polymerase chain reaction HSV = Herpes simplex $; \mathrm{CMV}=$ cytomegalovirus.

Swabs were taken from the ulcerative lesions of the nose and right upper eyelid (Fig. 1). Nucleic acid was extracted from $200 \mu \mathrm{L}$ of the sample by using Wizard ${ }^{\circledR}$ Genomic DNA Purification Kit (Promega, Madison, WI, USA). Briefly, $200 \mu \mathrm{L}$ of nuclei lysis solution and $2 \mu \mathrm{L}$ of RNase solution were added to $200 \mu \mathrm{L}$ of the clinic sample, in a 1.5 $\mathrm{mL}$ Eppendorf tube. The sample was mixed by inverting the tube five times, then it was incubated at $37^{\circ} \mathrm{C}$ for 30 minutes, and cooled to room temperature for five minutes. Next, $130 \mu \mathrm{L}$ of protein precipitation solution was added, and the tube was vigorously vortex-mixed for 10 to 20 seconds and placed on ice by five minutes. The tube was centrifuged at $13,000 \mathrm{x} g$ for four minutes at room temperature and the supernatant was transferred to a new tube containing $600 \mu \mathrm{L}$ of isopropanol. The sample was mixed by inversion and incubated at room temperature for 30 minutes; after which it was centrifuged at $13,000 \mathrm{x}$ g for one minute and the supernatant was discarded; $600 \mu \mathrm{L}$ of 70 ethanol was added and the tube was gently inverted to wash the pellet; centrifugation was performed at 13,000 $\mathrm{x} g$ for one minute. Ethanol was aspirated; the tube was inverted on a clean absorbent paper and the pellet was air-dried for 10 to 15 minutes; finally, $60 \mu \mathrm{L}$ of DNA Rehydration Solution was added and the DNA was rehydrated by incubating the solution at $65^{\circ} \mathrm{C}$ for one hour. The DNA was stored at $4{ }^{\circ} \mathrm{C}$ until the time of use.

Specimens were analyzed by conventional PCR assays, as previously described, for the presence of HSV types 1/2, Varicella-zoster virus (VZV), EBV, cytomegalovirus (CMV), HHV-6, HHV-7, and HHV-8. PCR products were detected by agarose gel electrophoresis and staining with ethidium bromide.

For HSV, VZV, EBV and CMV, a multiplex nested PCR protocol was used. First-round PCR reactions, consisting of $5 \mu \mathrm{L}$ of extracted DNA, were added to $20 \mu \mathrm{L}$ PCR mix containing $0.5 \mu \mathrm{M}$ of each HHV-F1 and HHV-R1 primers, $0.125 \mu \mathrm{M}$ of each VZV-F1 and VZV-R1 primers, and $1 \mathrm{X}$ PCR buffer; $1.5 \mathrm{Mm} \mathrm{MgCl}$ 0.2 Mm dNTPs; 2.5 U GoTaq DNA polymerase (Promega) was performed. First-round PCR was carried out using the following programs: one cycle at $94{ }^{\circ} \mathrm{C}$ for three minutes followed by 35 cycles at $94^{\circ} \mathrm{C}$ for 45 seconds, $65.5^{\circ} \mathrm{C}$ for one minute, 72 ${ }^{\circ} \mathrm{C}$ for one minute, and a final extension at $72{ }^{\circ} \mathrm{C}$ for seven minutes. For the nested PCR, $0.5 \mu \mathrm{L}$ of first-round product was transferred to $25 \mu \mathrm{L}$ of an identical PCR mix, with the same concentration as the first-round, but containing second-round primers (HHV-F1, HHV-R1, VZV-F2, and VZV-R2). PCR conditions were the same as the first-round, except the annealing temperature which was changed to $63{ }^{\circ} \mathrm{C}$. Positive and negative controls were included in each run. The expected sizes of the PCR products were as follow: HSV $1 / 2-742 \mathrm{pb}, \mathrm{VZV}-650 \mathrm{pb}, \mathrm{EBV}$ - 748pb, and CMV - 817pb (first-round PCR); HSV 1/2 - 493pb, VZV - 356pb, EBV - 499pb, and CMV - 565pb (nested PCR).
For HHV-6, a nested PCR protocol was performed using the same PCR reaction mixture described before. First-round PCR was carried out using the previously described 661 and 662 primers, that amplify a fragment of $325 \mathrm{bp}$ or 553bp for HHV-6 variants A and B, respectively. The samples were subjected to one cycle at $94{ }^{\circ} \mathrm{C}$ for five minutes, followed by 30 cycles at $94{ }^{\circ} \mathrm{C}$ for one minute, $50{ }^{\circ} \mathrm{C}$ for one minute, 72 ${ }^{\circ} \mathrm{C}$ for one minute, and a final extension at $72{ }^{\circ} \mathrm{C}$ for ten minutes. For the nested PCR, $0.5 \mu \mathrm{L}$ of first-round product was transferred to $25 \mu \mathrm{L}$ of an identical PCR mix, but containing second-round 663 and 664 primers that generate a fragment of 195bp for HHV-6 variant A or a fragment of $423 \mathrm{bp}$ for variant B. PCR conditions were the same as the first-round, except the annealing temperature which was changed to $60{ }^{\circ} \mathrm{C}$.

For HHV-7, the PCR reaction mixtures were similar to the one described previously. For the first-round PCR, we used HHV-7F1 and HHV-7R1 primers, that amplify a fragment of 309bp. The samples were subjected to one cycle at $94{ }^{\circ} \mathrm{C}$ for five minutes, followed by 35 cycles at $95{ }^{\circ} \mathrm{C}$ for 30 seconds, $55^{\circ} \mathrm{C}$ for 30 seconds, $72{ }^{\circ} \mathrm{C}$ for 30 seconds, and a final extension at $72{ }^{\circ} \mathrm{C}$ for ten minutes. For the nested PCR, $0.5 \mu \mathrm{L}$ of first-round product was transferred to $25 \mu \mathrm{L}$ of an identical PCR mix containing second-round HHV-7F2 and HHV-7R2 primers that amplify a fragment of $158 \mathrm{bp}$. The second-round comprised 35 cycles of the same thermal profile as the one described for the first-round PCR.

HHV-8 was also detected by PCR assay. The PCR reaction mixtures were similar to the one described for the other viruses. First-round PCR was carried out using the following program: one cycle at $95{ }^{\circ} \mathrm{C}$ for 15 minutes, followed by 35 cycles at $94^{\circ} \mathrm{C}$ for three seconds, $55^{\circ} \mathrm{C}$ for 30 seconds, $72^{\circ} \mathrm{C}$ for 30 seconds, and a final extension at $72^{\circ} \mathrm{C}$ for ten minutes, using KS1 and KS2 primers that amplify a fragment of 233bp. For the nested PCR, $0.5 \mu \mathrm{L}$ of first-round product was transferred to $25 \mu \mathrm{L}$ of an identical PCR mix containing second-round NS1 and NS2 primers that amplify a fragment of $160 \mathrm{bp}$. PCR conditions were the same as those of the first-round, except the annealing temperature which was changed to $65^{\circ} \mathrm{C}$.

To confirm the specificity of PCR products, the amplified DNAs of positive samples were purified by using Wizard SV gel and PCR Clean-Up System kit (Promega), and the sequences determined by using BigDye ${ }^{\circledR}$ Terminator Cycle Sequencing kit and ABI PRISM® 3100 automated DNA sequencer (Applied Biosystems, Foster City, CA, USA). DNA sequences were edited with Chromas (Technelysium Pty Ltd, Australia) and were compared to the DNA sequences available in GenBank® (www.ncbi.nlm.nih.gov) by using BLAST tool (www.ncbi. nlm.nih.gov/BLAST).

\section{RESULTS}

The sample collected from the lesion on the nose was negative for all eight viruses tested. The lesion started to heal before the therapy with acyclovir. But the lesion on the right upper eyelid was positive for HSV-1 (Fig. 3). It started to heal only after the treatment with acyclovir.

\section{DISCUSSION}

There are several ways to explain the pathogenesis of the relationship between infectious agents and pemphigus ${ }^{4}$. Infectious agents can stimulate the immune response in genetically susceptible individuals, leading to an increase of the production of interferon and interleukins ${ }^{21}$. 


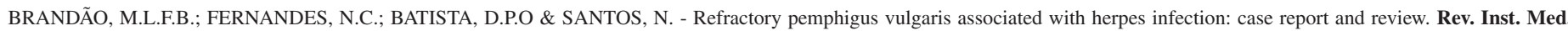
Trop. Sao Paulo, 53(2): 113-7, 2011

4 1234557 |

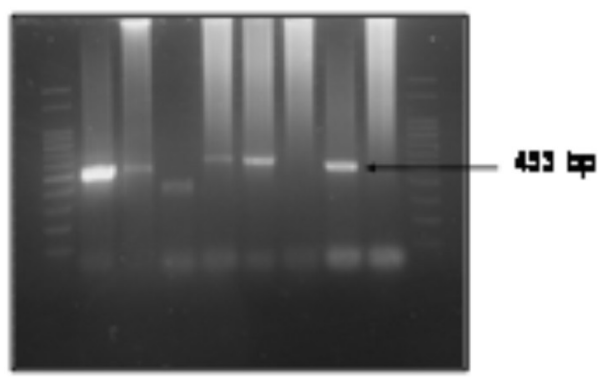

Fig. 3 - Lane 7 positive result for HSV-1 from the lesions of the right upper palpebra.

High levels of interferon-gamma induce the expression of HLA type 2 in the membranes of keratinocytes, making the structural site of PV antigen (epitope spreading) immunologically active ${ }^{21}$.

Chronic viral infections can also generate excessive production of IL-4 and IL-10, which cause a shift from TH1 to TH2 response, increasing antibody production. They can also directly infect $\mathrm{B}$ and $\mathrm{T}$ lymphocytes, contributing to the production of autoreactive B lymphocytes and autoimmune antibodies.

When infected, the keratinocytes can pass through structural changes which favor the exposure of antigens ${ }^{21}$. It is also relevant to observe that the majority of PV patients are treated with immunosuppressive therapy, which favors viral opportunistic infections ${ }^{4}$, often with atypical clinical presentation, as described by HALE \& BYSTRYN ${ }^{10}$ and KALAJIAN \& CALLEN ${ }^{11}$

Several cases of HSV as a trigger or as something which worsens PV have been described in literature (Table 1). It is observed that, in such cases, the complete remission of lesions has only occurred after introducing antiviral treatment, in the majority of cases, acyclovir.

KRAIN $^{14}$ was the first to report, in 1974, the possible role of viruses, especially HSV, in the pathogenesis of PV. In an epidemiological study with 59 patients with the disease, it emphasized the fact that two patients had developed pemphigus after showing severe herpetic infection.

TUFANO et al. ${ }^{27}$ have investigated the presence of infection caused by herpes virus 1/2, EBV, CMV, and HHV-6 in 20 patients with pemphigus. The authors have used serology and PCR in peripheral blood mononuclear cells (PBMC) and in biopsy samples. Regarding herpes simplex virus and cytomegalovirus, the results have been the following: 19 patients have had positive serology for CMV and HSV; using PCR method, 10 patients have been positive for HSV and none for CMV.

RUOCCO et al. ${ }^{20}$ have described a case of a hemophiliac child who has developed pemphigus foliaceus (PF) and has simultaneously shown high titers of anti-CMV antibodies, concluding that the CMV infection has possibly represented a trigger for the disease. The child has been treated with steroids and the titers of anti-CMV have followed the PF activity, reducing with the remission of the disease.

With the purpose of endorsing their hypothesis, RUOCCO et al. have measured anti-CMV antibodies in 16 patients with pemphigus, finding significant positive results in only one case. They have concluded that CMV infection can eventually lead to an occurrence of pemphigus in genetically susceptible patients.

We decided not to treat CMV in our patient, countering laboratorial evidence (sample with positive PCR), because of her medical condition and the possibility of hematologic toxicity by gancyclovir. Our patient's treatment included cyclophosphamide, essential drug to control the activity of PV, but with considerable potentiality for hematologic toxicity. Therefore, we considered it a high risk to associate another drug with the same pattern of toxicity to her treatment. This is in agreement with other authors who decided not to treat recalcitrant oral lesions positive for $\mathrm{CMV}^{12}$.

CMV infection usually occurs in patients with advanced immunosuppression and leads to constitutional symptoms, such as fever and malaise. It can cause esophagitis, colitis, hepatitis, retinitis, meningoencephalitis, pneumonia, and bone marrow suppression ${ }^{7,13}$. Dermatoses caused by CMV are rare and usually associated with disseminated infection ${ }^{7,13}$. The most common dermatological cases are mucosal necrosis and ulceration in perianal, genital, and perineal regions $s^{7,13}$. Regarding our patient, although she did not have any of these symptoms, we believe that an asymptomatic infection could be causing the persistence of the lesion.

As the lesion persisted for two months, another sample was collected and submitted to PCR analysis. With the positive result for HSV infection, acyclovir therapy was successfully established and the lesion finally healed.

OLIVEIRA et al. ${ }^{16}$ have described the case of a patient with PV who has healed the skin lesions after immunosuppression, maintaining the oral lesions. Searching for viral etiology to elucidate the refractoriness of the mucosal lesions, they have investigated the presence of HSV 1/2, VZV, EBV, CMV, HHV-6, HHV-7, and HHV-8 using PCR, finding positive results for HSV-1 and HHV-7. The treatment with acyclovir has succeeded and all lesions have been completely healed.

GRUNWALD et al. ${ }^{9}$ have published the case of a patient with PV and serious oral lesions with no response to corticosteroid therapy. Multinucleated cells and inclusion bodies have been detected in a cytological study of the lesions, besides the anti-HSV positive serology, confirming the hypothesis of PV aggravated by associated herpetic infection. Furthremore, BROWN \& TAYLOR ${ }^{5}$ and PRENDIVILLE et $a l .{ }^{18}$ have also published cases of PV and recalcitrant oral lesions, due to associated herpetic infection.

SCHLUPEN et al. ${ }^{23}$ have described three cases of pemphigus with mucosal exacerbation, which have failed with immunosuppressive therapy and have only succeeded after the addition of antiviral treatment. In those cases, DNA of HSV has been demonstrated in research with PCR in the lesions. Therefore, we believe that lesions of Pemphigus vulgaris that are unresponsive to the conventional treatment with corticosteroids should be submitted to viral investigations.

\section{CONCLUSIONS}

Several attempts have been made to isolate the infectious pathogens which induce or exacerbate pemphigus ${ }^{19}$, through techniques such as 
immunohistochemistry, viral isolation, and PCR for DNA particles (fast and sensitive technique). When the infectious agent is isolated, the combination of antiviral agent and immunosuppressive therapy has an important role, principally in cases with refractoriness to conventional therapy ${ }^{4,21}$. However, the therapeutic decision concerning the treatment of the isolated virus must comply with some parameters, such as the evaluation of the toxicity of the specific antiviral and the clinical evolution of the patient.

\section{RESUMO}

\section{Pênfigo vulgar refratário com infecção herpética associada: relato de caso e revisão da literatura}

Introdução: Pênfigo vulgar (PV)é uma doença auto-imune caracterizada por bolhas na pele e mucosas, que se desenvolve devido a interações entre predisposição genética e fatores ambientais. Infecções por vírus da família herpesviridae são sugeridos como possíveis gatilhos para PV. Objetivos e Métodos: Neste relato investigamos a presença de viroses herpéticas em lesão refratária da pálpebra superior direita de uma paciente portadora de PV.A lesão persistiu mesmo após tratamento com corticoesteróides. Reação em cadeia da polimerase (PCR) e análise de sequenciamento de DNA foram usados para detectar o DNA do HSV1/2, VZV, EBV, CMV, HHV-6, HHV-7, e HHV-8. Resultados: A amostra coletada da pálpebra superior direita foi positiva para HSV1/2. O seqüenciamento confirmou o resultado do PCR e identificou a cepa do HSV pertencendo ao tipo 1. Após o tratamento com aciclovir a lesão foi cicatrizada e não recidivou. Conclusão: Quando pacientes portadores de PV forem refratários à corticoterapia, infecção herpética deverá ser considerada.

\section{REFERENCES}

1. Amagai M. Pemphigus as a paradigm of an autoimmune and cell adhesion. Keio J Med. 2002;51:133-9.

2. Andreadis D, Lorenzini G, Drakoulakos D, Belazi M, Mihailadou E, Velkoos, G. et al. Detection of pemphigus desmoglein 1 and desmoglein 3 autoantibodies and pemphigold BP180 autoantibodies in saliva and comparison with serum values. Eur J Oral Sci. 2006;114:374-80.

3. Brenner S, Mashiah J, Wohl Y. Pênfigos. In: Ramos-e-Silva M, Castro MCR Fundamentos de dermatologia. Rio de Janeiro: Atheneu; 2009. p. 605-615.

4. Brenner S, Sasson A, Sharon O. Pemphigus and infections. Clin Dermatol. 2002;20:114-8.

5. Brown P, Taylor B. Herpes simplex infection associated with pemphigus vulgaris: case report and literature review. J Acad Dermatol. 1989;21:1126-8.

6. Cunha PR, Barraviera SRCS. Dermatoses bolhosas auto-imunes. An Bras Dermatol. 2009;84:111-24

7. Gaffar BA, Raman LG, Muala AA. Cutaneous cytomegalovirus infection in a patient with acquired immunodeficiency syndrome. Int J Dermatol. 2008;47:944-6.

8. Grando SA. Pemphigus in the XXI Century: new life to an old story. Autoimmunity. 2006;39:521-30.

9. Grunwald MH, Katz I, Friedman-Birnbaum R. Association of pemphigus vulgaris and herpes simplex infection. Int J Dermatol. 1986;25:392-3.

10. Hale EK, Bystryn JC. Atypical herpes simplex can mimic a flare of disease activity in patients with pemphigus vulgaris. J Eur Acad Dermatol Venereol. 1999;13:221-3.
11. Kalajian AH, Callen JP. Atypical herpes simplex infection masquerading as recalcitrant pemphigus vulgaris. Australas J Dermatol. 2007;48:242-7.

12. Kalra A, Ratho RK, Kaur I, Kumar B. Role of herpes simplex and cytomegalo viruses in recalcitrant oral lesions of pemphigus vulgaris. Int J Dermatol. 2005;44:259-60.

13. Kaisar MO, Kirwan RM, Strutton GM, Hawley CM, Mudge DW, Campbell SB, et al. Cutaneous manifestations of cytomegalovirus disease in renal transplant recipients: a case series. Transpl Infect Dis. 2008;10:209-13.

14. Krain LS. Pemphigus: epidemiologic and survival characteristics of 59 patients, 1955-1973. Arch Dermatol. 1974;110:862-5.

15. Nikkels AF, Delvenne P, Herfs M, Pierard GE. Occult herpes simplex virus colonization of bullous dermatitides. Am J clin Dermatol. 2008;9:163-8.

16. Oliveira DP, Moura HH, Janini ME, Fernandes NC, Santos N. Diagnosis and treatment of persistent oral lesions caused by herpesvirus in a patient with pemphigus vulgaris. Int J Dermatol. 2011;50:335-9.

17. Oña M, Melón S, Rodriguez JL, Sanmartin JC, Bernardo MJ. Association between human herpesvirus type 6 and 7, and cytomegalovirus disease in heart transplant recipients. Transplant Proc. 2002;34:75-6.

18. Prendiville JS, Israel DM, Wood WS, Dimmick JE. Oral pemphigus vulgaris associated with inflammatory bowel disease and herpetic gingivostomatitis in a 11-year-old girl. Pediatr Dermatol. 1994:11:145-50.

19. Ruocco E, Baroni A, Wolf R, Ruocco V. Life-threatening bullous dermatoses: pemphigus vulgaris. Clin Dermatol. 2005;23:223-6.

20. Ruocco V, Wolf R, Ruocco E, Baroni A. Viruses in pemphigus: a casual or causal relationship? Int J Dermatol. 1996;35:782-4.

21. Sagi L, Sherer Y, Trau H, Shoenfeld Y. Pemphigus and infectious agents. Autoimmun Rev. 2008;8:33-5.

22. Schwartz RA, Grando SA. Pemphigus exacerbators. Skinmed. 2006;5:109-10.

23. Schlupen EM, Wollenberg A, Hänel S, Stumpenhausen G, Volkenandt M. Detection of herpes simplex virus in exacerbated pemphigus vulgaris by polymerase chain reaction. Dermatology. 1996;192:312-6.

24. Tafreshi NK, Sadeghizadeh M, Amini-Bavil-Olyaee S, Ahadi AM, Jahanzad I, Roostall MH. Development of a multiplex nested consensus and identification of major human herpesviruses in CNS infections. J Clin Virol. 2005;32:318-24.

25. Takahasi I, Kobayashi TK, Suzuki H, Nakamura S, Tezuka F. Coexistence of pemphigus vulgaris and herpes simplex virus infection in oral mucosa diagnosed by cytology, immunohistochemistry and polymerase chain reaction. Diagn Cytopathol. 1998; 19:446-50.

26. Tong JC, Sinha AA. Immunological hotspots analysed by docking simulations: evidence for a general mechanism in pemphigus vulgaris pathology and transformation. BMC Immunol. 2008;9:30.

27. Tufano MA, Baroni A, Buommino E, Ruocco E, Lombardi ML, Ruocco V. Detection of herpes virus DNA in peripheral blood mononuclear cells and skin lesions of patients with pemphigus by polymerase chain reaction. Br J Dermatol. 1999;141:1033-9.

28. Wang FZ, Dahl H, Linde A, Brytting M,Ehrnst A, Ljungman P. Lymphotropic herpesvirus in allogeneic bone marrow transplantation. Blood. 1996;88:3615-20.

Received: 28 June 2010

Accepted: 7 February 2011 


\section{LIBRARY OF THE SÃO PAULO INSTITUTE OF TROPICAL MEDICINE}

Website: www.imt.usp.br/portal

Address: Biblioteca do Instituto de Medicina Tropical de São Paulo da Universidade de São Paulo Av. Dr. Enéas de Carvalho Aguiar, 470. Prédio 1 - Andar térreo.

05403-000 São Paulo, SP, Brazil.

Telephone: 5511 3061-7003 - Fax: 5511 3062-2174

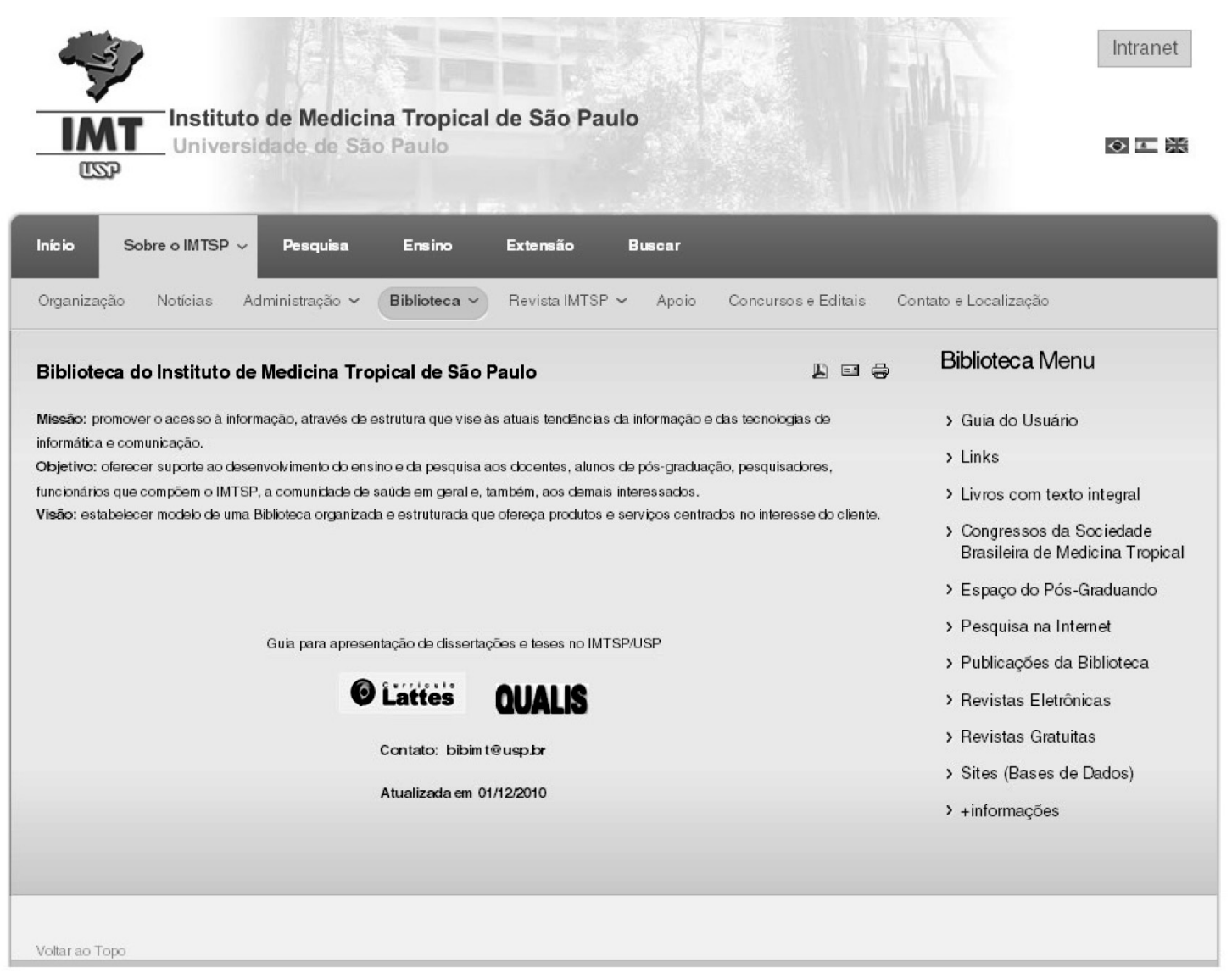

The Library of the São Paulo Institute of Tropical Medicine (IMTSP Library) was created on January 15,1959 in order to serve all those who are interested in tropical diseases. To reach this objective, we select and acquire by donation and / or exchange appropriate material to be used by researchers and we maintain interchange between Institutions thorough the Journal of the São Paulo Institute of Tropical Medicine, since the Library has no funds to build its own patrimony.

The IMTSP Library has a patrimony consisting of books, theses, annals of congresses, journals, and reference works.

The collection fo journals existing in the Library can be verified through the USP - Bibliographic Database - OPAC - DEDALUS http://dedalus.usp.br:4500/ALEPH/eng/USP/USP/DEDALUS/start of the USP network. 